\title{
Performance Comparison of Ethyl, Methyl and Butyl of Lemon Grass Oil in Di Engine
}

\author{
Purusothaman $\mathrm{M}^{1, *}$, Sai Manoj $\mathrm{P}^{2}$, \\ ${ }^{1}$ Assistant Professor, ${ }^{2}$ Student \\ School of Mechanical Engineering, \\ Sathyabama Institute of Science and Technology, Chennai-600119, \\ Tamilnadu, India.
}

\begin{abstract}
The world's energy situation become worst in developing industrialized countries, meanwhile it becomes depletion of common resources such as coal, crude oil, natural gas and even nuclear energy will became scary with next generation, the renewable sources such as hydro, wind, solar and bio energy are gaining more and more importance. SI engines using natural gas can run at higher compression ratios, thus producing higher thermal efficiency but also increased un burned hydrocarbon (HC) and carbon monoxide (co). Lemon grass oil Derived from lemon grass is considered as good alternative to petroleum fuels. The main aim of the project is to test the emission of 4-stroke engine using lemon grass oil with various blends like methyl, ethyl and butyl. The ethyl, methyl, butyl is mixed with lemon grass oil through transesterification, blending, pyrolysis, dilution processes. The comparison of performance, thermal efficiency, NOx emission, $\mathrm{CO}$ emission, hydrocarbon emission is determined through engine testing, however further refinement can be done through optimization of engine, fuel injection, compression ratio, etc. in system is needed. The best biodiesel blend is methyl. The optimum injection timing for methyl blend is $30^{\circ}$ bTDC. The optimum compression ratio for methyl blend is 19.5:1. The optimum injection pressure for methyl blend is 240 bars.
\end{abstract}

\section{INTRODUCTION}

In a project sponsored in National Renewable Energy Laboratory, the Gas Technology Institute (formerly Institute of Gas Technology) put an investigation of biodiesel fuels produced from various vegetable-and animal-based feed stocks. Due to the varying nature of the feed stocks and the processes for converting them into suitable biodiesel (methyl esters), an important part of the study has been the laboratory testing of the properties to determine the characteristics of each fuel [4].

The effort is conducted in three parts. The first segment of the project involved in the production of methyl esters from the various feed stocks and a review of the issues encountered with each feedstock. In second part, the biodiesels are subjected to a series of tests to document the properties of the methyl esters. With an understanding of the values and importance of each test, the specifications for acceptance of biodiesel were reviewed [3].

In the third part, the part of mixing biodiesel and diesel was studied, because in an understanding the basic properties does not necessarily indicate what will be happen as a result of mixing it with diesel fuel. Due to the cost, biodiesel commonly is mixed with diesel (instead of used straight, or "neat") to bring many of the useful characteristics to diesel equipment, while in reducing the overall cost of fuel. Because of different compositions and basic differences between biodiesel and diesel, some properties may vary in a non-intuitive manner, e.g., not varying linearity with respect to blend fraction. The testing analysis these effects of blending the multi-feedstock biodiesels with diesel over a variety of varying compositions [3].Increased in gas prices as well as a greater environmental concern, have led many Americans to search a better alternative to a conventional gasoline-powered automobile. [5].

It is evident to clear and unbiased information on this topic difficult to come by. Through in-depth research including an overall life-cycle cost, comparisons, and this analysis of other studies on the matter, the inquiries will be of importance to anyone who owns or it is planning to own a passenger or sport utility vehicle. The results will include in life costs, cost-to-benefit ratios, vehicle comparisons, and performance of statistics. The analysis will be divided into three groups; $20 \%$ city $-80 \%$ highway, and $80 \%$ city $-20 \%$ highways. These Figures will be based off these assumptions; 100,000-mile life spans over a ten-year period. The outcome in this research is to enlighten the general public in the financial and environmental concerns on the alternatives of gasoline [4].

$$
E=\text { Emissions }_{(\text {Carbon })}=\underbrace{\left(\frac{\text { Gallons }}{\text { Mile }}\right)}_{\text {Fuel Consumption }}(\underbrace{\left.\frac{\text { miles traveled }}{\text { Vehicle }}\right)}_{\text {Activity }}(\underbrace{\left.\frac{\text { mass C }}{\text { gallon }}\right)}_{\text {Carbon Content }}=F \times A \times C
$$

Prabhakar S et al (2012),From this research work, it is concluded that among various biodiesel blends, $20 \%$ of nerium and $80 \%$ of diesel blend at injection pressure of 240 bars with a standard injection timings of $27^{\circ}$ bTDC and with a standard compression ratio of 17.5:1 gives slightly better performance than diesel. Prabhakar S et al (2015), States that his experimental results also show that for N20 blend (best biodiesel blend), the optimum injection timing is $30^{\circ}$ bTDC, optimum compression ratio is $19.5: 1$ and optimum injection pressure is $240 \mathrm{bar}$. The experimental results show that $\mathrm{N} 20$ blend $(20 \%$ methyl ester of nerium with $80 \%$ of diesel) is found to be best biodiesel blend, which has higher brake thermal efficiency and lower HC, 
CO, Smoke emission and slightly increased NOX emission when compared to other biodiesel blends and has slightly reduced brake thermal efficiency and lower $\mathrm{HC}, \mathrm{CO}$, Smoke emission and slightly increased NOX emission when compared to diesel.

Prabhakar S et al (2013), states that the biodiesel has nearly $10 \%$ more oxygen which facilitates the combustion and enhances the cetane number (51).It also used as a fish poison, as the metabolites Karajan and pongamol are both toxic to fish. The biodiesel thus produced was made into different blends like B10, B20, B30, B40 and performed engine test and found many performance characteristics like brake thermal efficiency, brake specific fuel consumption and many emission characteristics like $\mathrm{CO} 2$, $\mathrm{CO}, \mathrm{NOx}, \mathrm{HC}, \mathrm{O} 2$ and smoke emissions. Akoh et al (2007),shows that there is a current interest in using enzymatic catalysis to commercially convert vegetable oils and fats to FAME as biodiesel fuel, since it is more efficient, highly selective, involves less energy consumption (reactions can be carried out in mild conditions) and produces less side products or waste (environmentally favorable) (However, the drawbacks of enzymatic catalysts are significantly higher production cost as well as difficulty during manufacturing due to the need for a careful control of reaction parameters [1].

Antczak et al (2007),states that in his research work engineering of enzymatic biodiesel synthesis processes requires optimization of such factors as: molar ratio of substrates (alcohol: triacylglycerol's), temperature, type of organic solvent (if any) and water activity. All of them are correlated with properties of lipase preparation. In addition, knowledge about water content, free fatty acid level, percent conversion, acyl migration and substrate flow rate in packed bed bioreactors) are required to improve the yield of biodiesel. For the use of enzymes, there are some critical factors: There is a minimum water content needed by the lipase, below which it does not work; alcohol has an effect on the reaction, being methanol the most commonly employed; the effect of temperature effect is significant because instead of increasing the reaction rate by increasing temperature, enzymes can become denatured at high temperatures; and obviously the raw material is important, because not all oils have the same amount [2].

The best biodiesel blend is methyl. The optimum injection timing for methyl blend is $30^{\circ}$ bTD. The optimum compression ratio for methyl blend is $19.5: 1$. The optimum injection pressure for methyl blend is 240bar. When compared with other injection timings, compression ratios and injection pressures, the maximum brake thermal efficiency and reduced emission for methyl blend are obtained at injection pressure of 240bar.

The blends are tested for brake thermal efficiency, NOx emission, CO emission, hydrocarbon emission, cylinder pressure etc. These tests are made separately for various blends of lemon of lemon grass oil in the testing engine. In the tests made in various lemon grass oil blends, the methyl lemon grass oil gives a better output. The methyl blended lemon grass oil gives a better brake thermal efficiency when compared to other blends. Thus, the methyl blended lemon grass oil is comparatively better than ethyl, butyl blended lemon grass oil. Pradeep et al (2020) studied the effect of variable compression ratio engine performance fueled with Biodiesel from waste cooking oil [14]. Purusothaman et al (20200 has reported the experimental Validation on PCCI Engine Fuel with Madhuca Indica Blends [13]. The small modification on engine leads to small engine performance changes are reported by various articles [9-12].

\section{EXPERIMENTATION}

\subsection{TESTING ENGINE}

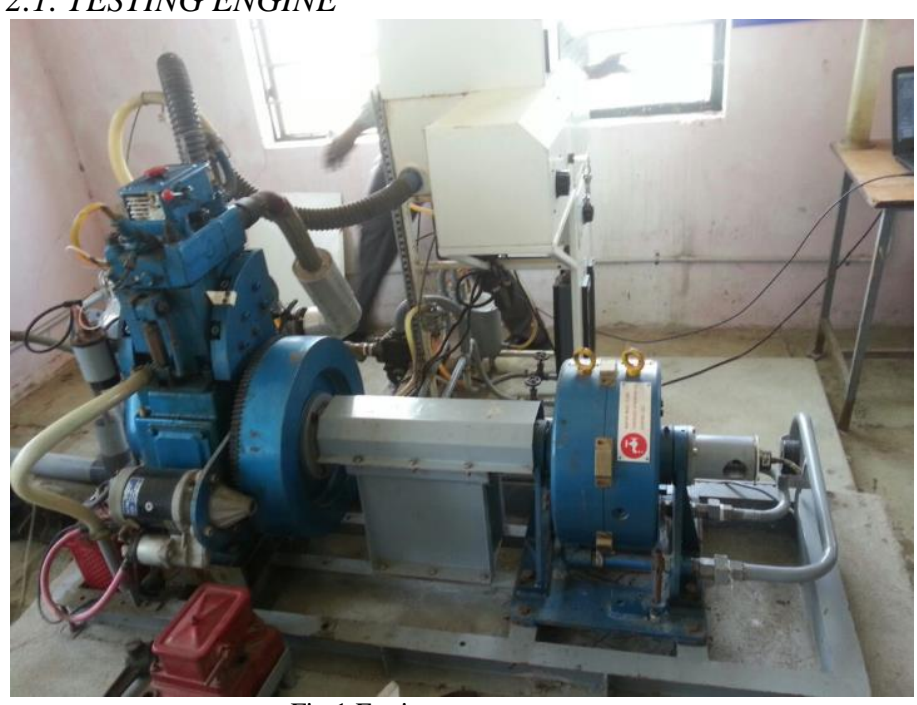

Fig.1 Engine test set up

Variable compression ratio is a technology to adjust the compression ratio of an internal combustion engine while the engine is in operation. This is done to increase fuel efficiency while under varying loads. Higher loads require lower ratios to be more efficient and vice versa. Variable compression engines allow for the volume above the piston at 'Top dead centre to be changed. For automotive use this needs to be done dynamically in response to the load and driving demands.

Table 1 Engine specification

\begin{tabular}{|l|l|}
\hline Product & $\begin{array}{l}\text { Research engine test setup 1 cylinder, 4 stroke } \\
\text { multifuel VCR with open ECU petrol mode } \\
\text { (computerized). }\end{array}$ \\
\hline Product code & 240 PE \\
\hline Engine & $\begin{array}{l}1 \text { cylinder, 4 stroke, water cooled, stroke 110mm, } \\
\text { bore 87.5 mm, capacity 661cc } \\
\text { Diesel mode: power 3.5 KW, speed 1500 rpm, CR } \\
\text { range 12:1-18:1, injection variation 0-25 degree } \\
\text { BTDC } \\
\text { ECU petrol mode: power 3.5 KW @ 1500rpm, } \\
\text { speed range 1200-1800 rpm, CR range 6:1-10:1 }\end{array}$ \\
\hline Dynamometer & Type eddy current, water cooled with loading unit. \\
\hline Fuel tank & $\begin{array}{l}\text { Capacity 15 lit, double compartment, with fuel } \\
\text { metering pipe of glass. }\end{array}$ \\
\hline Peizo sensor & Combustion range 5000 Psi \\
\hline Crank angle sensor & Resolution 1 deg, speed 5500 rpm with TDC pulse \\
\hline $\begin{array}{l}\text { Data acquisition } \\
\text { test }\end{array}$ & NI USB-6210, 16 bit, 250kS/s \\
\hline $\begin{array}{l}\text { Engine } \\
\text { hardware control }\end{array}$ & Fuel injector, fuel pump, ignition coil, idle air \\
\hline $\begin{array}{l}\text { Temperature } \\
\text { sensor }\end{array}$ & Type RTD, PT 100 and thermocouple, type K \\
\hline Load indicator & Digital, range 0-50 kg, supply 230 VAC \\
\hline
\end{tabular}




\begin{tabular}{|l|l|}
\hline Load sensor & Load cell, type strain gauge range 0-50Kg \\
\hline Software & "Engine soft" engine performance analysis software \\
\hline ECU software & premonitory \& previewer software \\
\hline Makes & Apex innovation private ltd \\
\hline
\end{tabular}

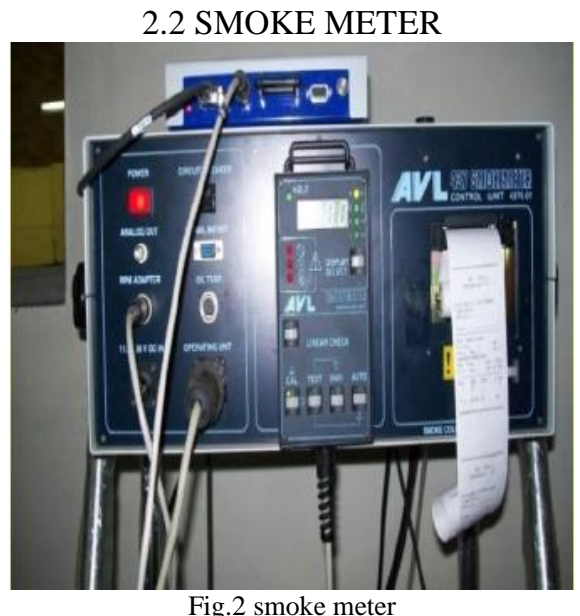

\subsection{ELECTRICAL DYNAMOMETER}

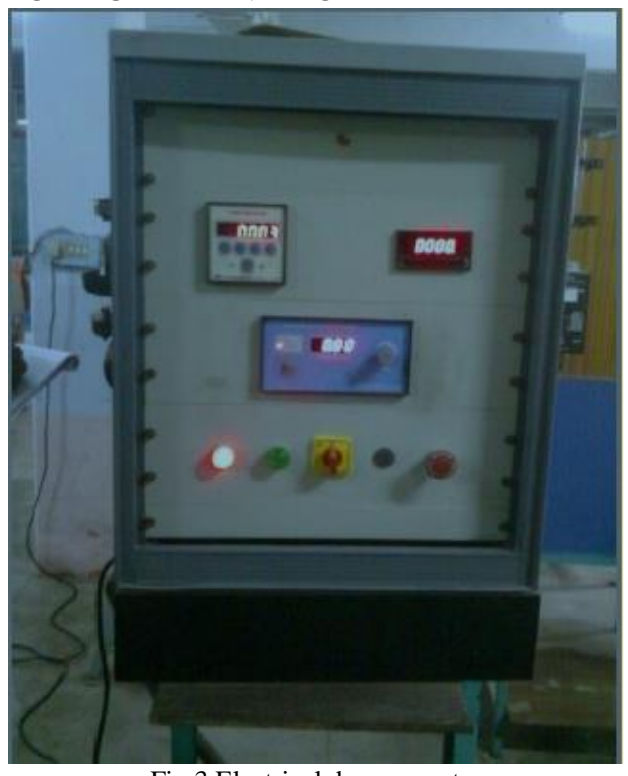

Fig.3 Electrical dynamometer

\subsection{DATA ACQUISATION SYSTEM}

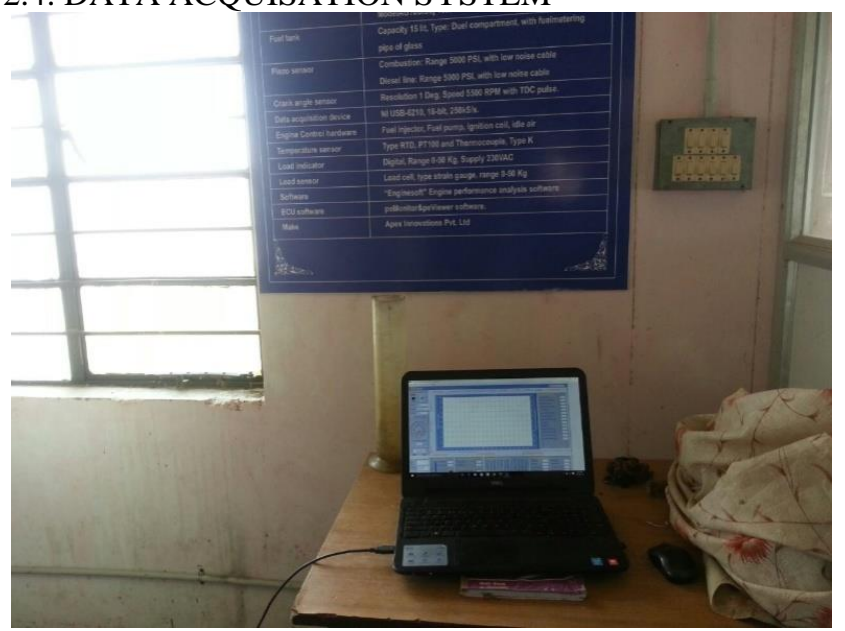

Fig.4 data acquisition system

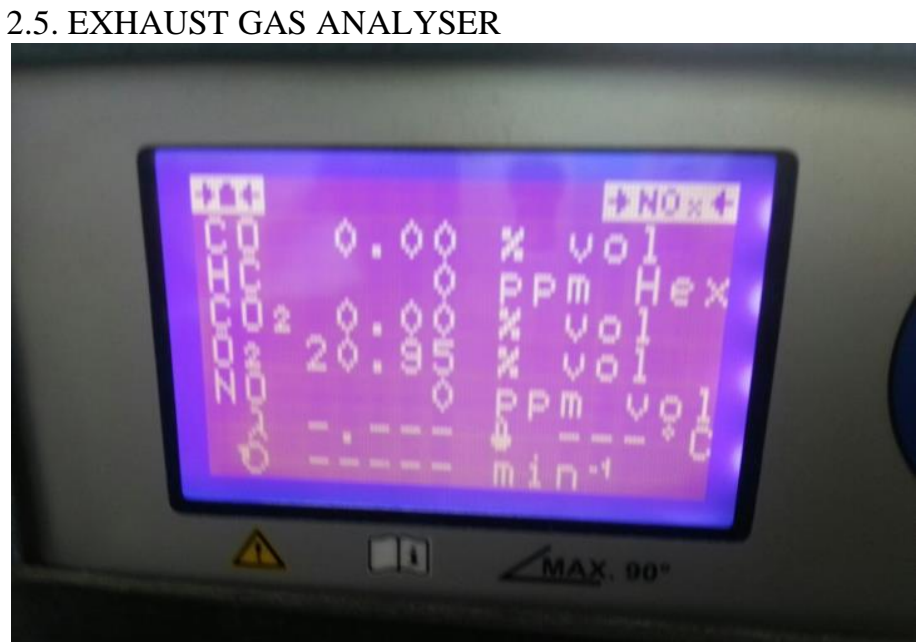

Fig.5 Exhausts gas analyzer.

\section{RESULTS AND DISCUSSION}

Hence the lemon grass oil is tested for performance is calculated with different mixtures (Ethyl, Methyl and Butyl) is done successfully and their results are as follows.

\subsection{PERFORMANCES OF VARIOUS LEMON GRASS OIL BLENDS}

The readings are taken from the smoke meters and calculated efficiency parameter. Graphs are plotted accordingly to the known values. Here the performances and emissions are taken and the values are taken with the comparison of ethyl, methyl and butyl.

\subsection{COMPARISION OF BRAKETHERMAL EFFICIENCY}

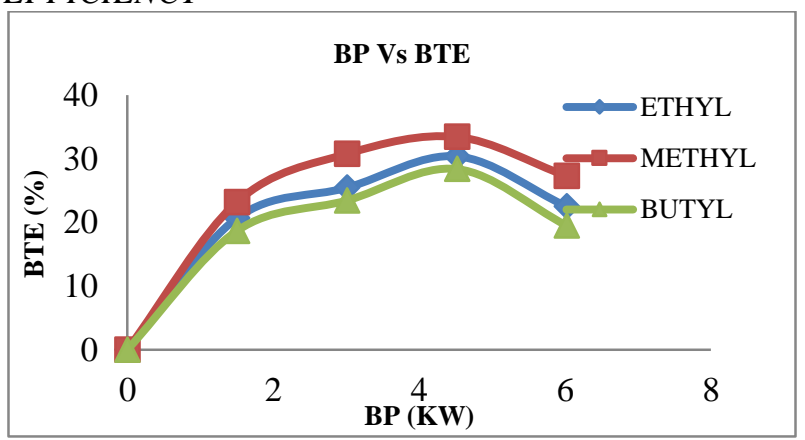

Fig.6 Comparison of Brake Power Vs Brake Thermal Efficiency

Methyl blend at 19.5:1, at three fourth of load the maximum brake thermal efficiency was obtained when compared to other compression ratios at three fourth of load. This may be due to better mixing of the fuel-air inside combustion chamber which results in better combustion. For methyl blend at 20.5:1, at three fourth of load the brake thermal efficiency decreases by $1.25 \%$ when compared to methyl blend at 19.5:1 at three fourth of load. This may be due to the poor fuel-air mixture formation which results in lower combustion. For methyl blend at 16.5:1, at three fourth of load the brake thermal efficiency decreases by $1.66 \%$ when compared to methyl blend at 17.5:1 at three fourth of load. This may be due to the poor flammability during combustion, which results in incomplete combustion. 
3.3 COMPARISON OF SPECIFIC ENERGY CONSUMPTION

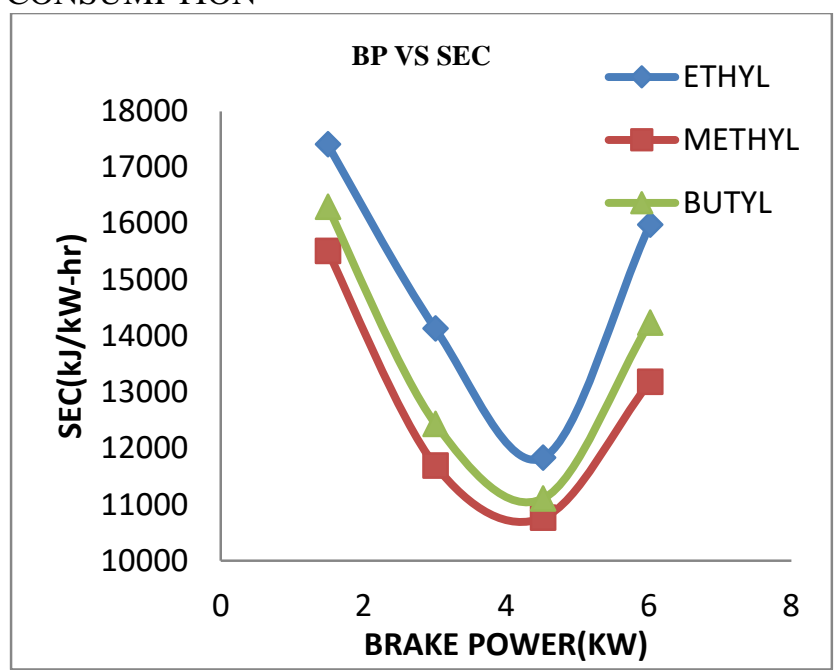

Fig.7 Comparison of Brake Power Vs Specific Energy Consumption

Methyl blend at 19.5:1, at maximum load the lower specific energy consumption was obtained when compared to other compression ratios at maximum load. This may be due to the proper rate of evaporation of the biodiesel, which results in better combustion. For methyl blend at 20.5:1, at maximum load the specific energy consumption increases by $2.8 \%$ when compared to methyl blend at 19.5:1 at maximum load. This may be due to the diminishing role of fuel oxygen, which leads to high air-fuel mixture and turbulence intensity at high compression ratio. For methyl blend at16.5:1, at maximum load the specific energy consumption at increases by $12.57 \%$ when compared to methyl blend at 17.5:1 at maximum load. This may be due to the poor fuel spray patterns, which leads to incomplete combustion at low compression ratio.

\subsection{COMPARISON OF CO2 EMISSIONS}

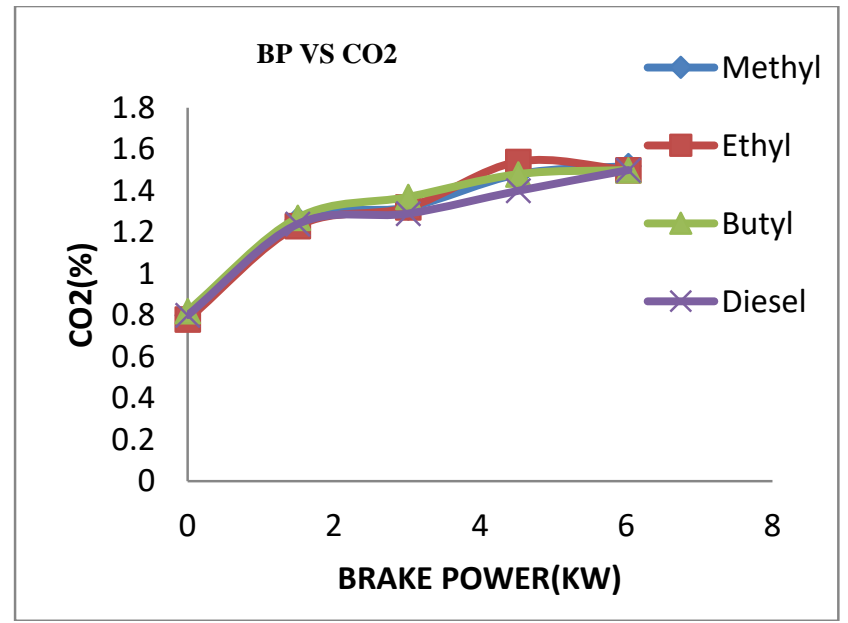

Fig.8 Comparison of Brake Power VS Carbon di oxide

Carbon dioxide emissions of ethyl, methyl and butyl are compared with pure diesel. By observing the graph, we can see the ethyl emissions are slightly higher. In the blend mixture, we can find methyl mixture gives low emissions compared to that of butyl and ethyl. This may be due to the high premixed burning rate which decreases the flame temperature. Here we can observe the change in the emissions which were occurred in the comparison. Actually, we can see the graph parameter as a part in which that variation of the graph will be modified accordingly to the known parameters with the increase in the ethyl, methyl and butyl but here the emissions are not good accordingly compared to diesel. Diesel emissions are good compared to that of our blends

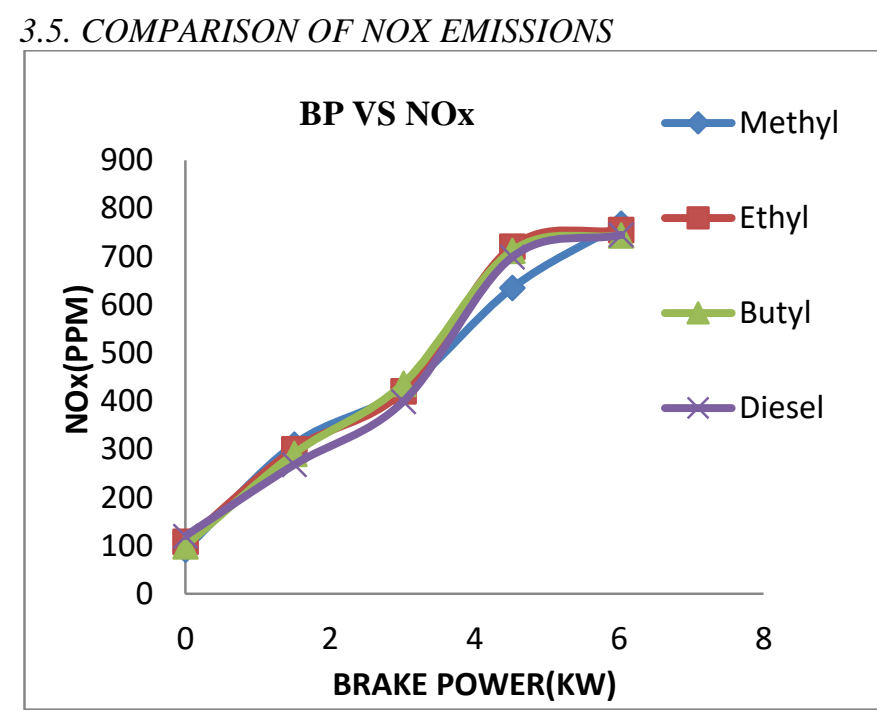

Fig.9 Comparison of Brake Power vs nitrogen oxide

Methyl blend at 19.5:1, at maximum load the higher NOX emission was obtained when compared to other compression ratios at maximum load. This may be due to the proper atomization and better flammability, which causes larger amounts of NOX formation. For methyl blend at 20.5:1, at maximum load the NOX emission decreases by $4.0 \%$ when compared to ethyl blend at $19.5: 1$ at maximum load. This may be due to the high premixed burning rate which decreases the flame temperature. For methyl blend at $16.5: 1$, at maximum load the NOX emission decreases by $15.11 \%$ compared to ethyl blend at 17.5:1 at maximum load. This may be due to the poor combustion and spray characteristics, the oxygen content in the fuel is not fully burnt which results in lower emission.

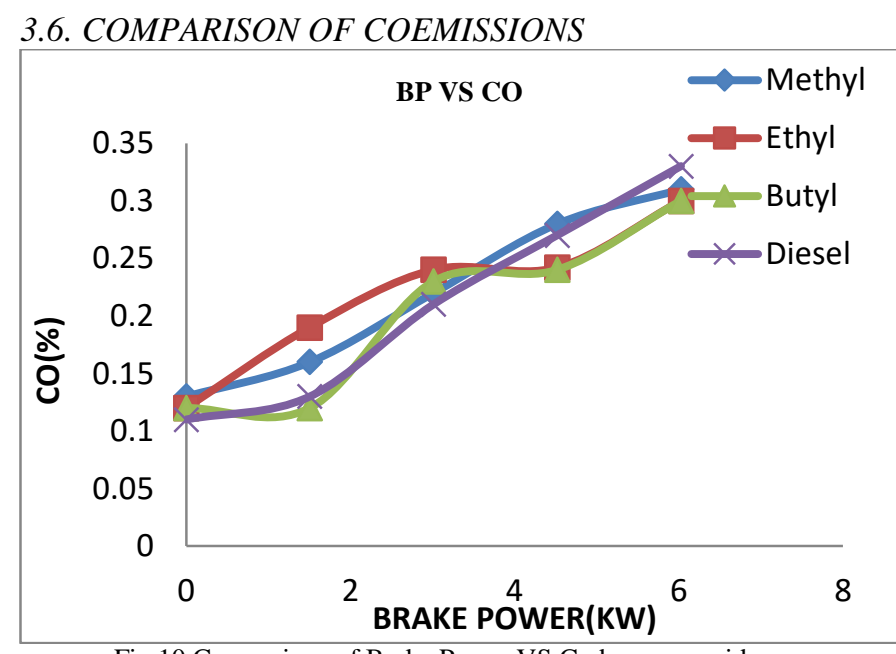

Fig.10 Comparison of Brake Power VS Carbon monoxide 
Butyl blend at 19.5:1, at maximum load the lower CO emission was obtained when compared to other compression ratios at maximum load. This may be due to the possibility of proper combustion at this compression ratio. For methyl blend at 20.5:1, at maximum load the $\mathrm{CO}$ emission increases by $0.004 \%$ when compared to methyl blend at 19.5:1 at maximum load. This may be due to rich fuel-air ratio, which contributes to an incomplete fuel oxidation. For butyl blend at 16.5:1, at maximum load the $\mathrm{CO}$ emission increases by $0.003 \%$ compared to N20 blend at $17.5: 1$ at maximum load. This may be due to the insufficient oxygen content during the combustion.

\subsection{COMPARISON OF HC}

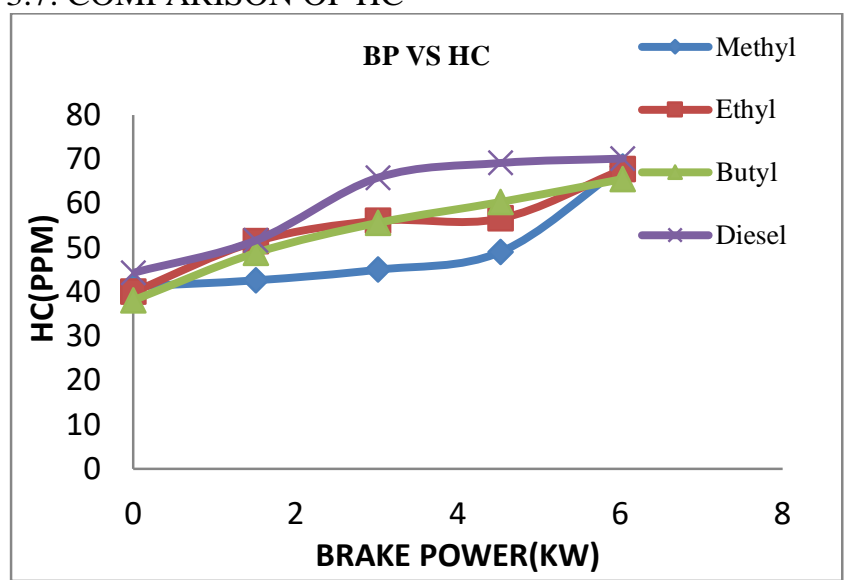

Fig.11 Comparison of Brake Power VS Hydro carbon

For butyl blend at 19.5:1, at maximum load the lower HC emission was obtained when compared to other compression ratio set maximum load. This may be due to the homogeneity of fuel-air mixture which results in better combustion. For butyl blend at 20.5:1, at maximum load the HC emission increases by $4.4 \%$ when compared to methyl blend at 19.5:1 at maximum load. This may be due to the high surface tension effect which affects the mixing of fuel and air which results in lower combustion. For methyl blend at 16.5:1, at maximum load the $\mathrm{HC}$ emission increases by $10.52 \%$ compared to butyl blend at 17.5:1 at maximum load. This the comparison of brake thermal efficiency, specific energy consumption, hydrocarbon emission, NOx emission, $\mathrm{CO}$ emission, cylinder pressure, heat release rate etc of various lemon grass oil blends (ethyl, methyl, butyl).

\section{CONCLUSIONS}

The best biodiesel blend is methyl. The optimum injection timing for methyl blend is $30^{\circ}$ bTD. The optimum compression ratio for methyl blend is 19.5:1.The optimum injection pressure for methyl blend is 240bar. When compared with other injection timings, compression ratios and injection pressures, the maximum brake thermal efficiency and reduced emission for methyl blend are obtained at injection pressure of 240 bars.

The blends are tested for brake thermal efficiency, NOx emission, $\mathrm{CO}$ emission, hydrocarbon emission, cylinder pressure etc. These tests are made separately for various blends of lemon of lemon grass oil in the testing engine.
The results of ethyl, methyl, and butyl lemon grass are calculated and tabulated above for comparison. The comparison graphs are drawn for each test for a better comparison for selection of best blend. In the tests made in various lemon grass oil blends, the methyl lemon grass oil gives a better output. The methyl blended lemon grass oil gives a better brake thermal efficiency when compared to other blends. Thus the methyl blended lemon grass oil is comparatively better than ethyl, butyl blended lemon grass oil.

\section{REFERENCES}

[1] Akoh, C. C., Chang, S.-W., Lee, G.-C., \& Shaw, J.-F. (2007) Enzymatic Approach to Biodiesel Production. Journal of Agricultural and Food Chemistry, 55(22), 8995-9005.

[2] Szczęsna Antczak, M., Kubiak, A., Antczak, T., \& Bielecki, S. (2009). Enzymatic biodiesel synthesis - Key factors affecting efficiency of the process. Renewable Energy, 34(5), 1185-1194.

[3] "Blue Tec Clean Diesel." Blue TEC: The Greenest Blue There Is. Mercedes Benz. 16 Dec 2008 .vol.6(121-124)

[4] Brett, Hulsey. "Ethanol: A convenient Solution to the 'Inconvenient Truth'." Moderate Ethanol Blends Can Save Money, Reduce Pollution and Improve Mileage (2007):vol.2(87)

[5] Chalk, Steven. "Progress Report, Fuel Cells and Infrastructure Technologies Program." Energy Efficiency and Renewable Energy FY 2003(2003): Gable, Scott. "What is ULEV - Ultra Low Emissions Vehicle?." Hybrid Cars and Alt Fuels. About.com. 17 Dec 2008 vol.10 (341-356).

[6] Haas, M. J., Piazza, G. J., \& Foglia, T. A. (2002). Enzymatic approaches to the production of biodiesel fuels. Lipid biotechnology, vol 9. (587-598).

[7] Kalam, M. A., Masjuki, H. H., Jayed, M. H., \& Liaquat, A. M (2011). Emission and performance characteristics of an indirect ignition diesel engine fuelled with waste cooking oil. Energy, 36(1), 397-402.

[8] Prabhakar S,Prakash S,Saravana Kumar M,(2015), Effect of nerium biodiesel in diesel engine, Journal of Chemical and Pharmaceutical Sciences, Special Issue.9,247-251.

[9] Purusothaman, M., kota, S., Sam Cornilius, C., \& Siva, R. (2017). Experimental Investigation of Thermal Performance in a Vehicle Cabin Test Setup With Pcm in the Roof. IOP Conference Series: Materials Science and Engineering, 197, 012073.doi:10.1088/1757-899x/197/1/012073.

[10] Purusothaman M, Sunil Kumar M, Praveen kumar V, Suraj kumar, Senthamizh Selvan S, Design And Thermal Validation Of Four Wheeler Disc Brake Using Different Material, International Journal of Innovative Technology and Exploring Engineering (IJITEE) ISSN: 2278-3075, Vol.8 Issue-8, 2019, pp.1739-1764.

[11] Purusothaman M, Yogesh M, Vengatesan E, Vignesh B, Ramkumar A, "Design Modification and Improvement on Automobile Suspension System", International Journal of Innovative Technology and Exploring Engineering (IJITEE), ISSN: 2278-3075, Volume-8 Issue-11, September 2019, pp.277-281.

[12] M Purusothaman, T Jitendra Siva Prasad, J Mohan Krishna, K Manoj kumar, "Weight Reduction and Structural Validation of Four Wheeler Disc Brake with Various Materials" International Journal of Innovative Technology and Exploring Engineering, Volume-9 Issue-2, December 2019,pp-.

[13] M Purusothaman, Nama Sai Teja, Nallamilli Jnana Sai Vamsidhar Reddy ,Oduri Pavan Ram, Kommoju rohit subhramanyam, "Experimental Validation On PCCI Engine Fuel With Madhuca Indica Blends", International Journal Of Scientific \& Technology Research ,Volume 9, Issue 01, January 2020,pp-3037-3042.

[14] Pradeep uttam Gaikwad, Senthilkumar Gnanamani, M.purusothaman, S.Lakshmi sankar, J.Jeya jeevahan, "Performance Evaluation of Variable Compression ratio engine fueled with Biodiesel from waste cooking oil", Indian Journal of environmental protection, Vol.40, Issue -1, January 2020,pp,110112. 